\title{
Titanium-tantalum oxide as a support for Pd nanoparticles for the oxygen reduction reaction in alkaline electrolytes
}

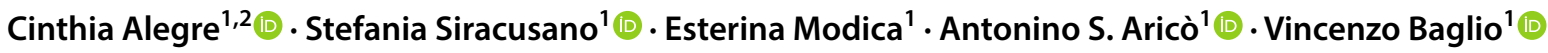

Received: 28 November 2017 / Accepted: 21 March 2018 / Published online: 28 March 2018

(c) The Author(s) 2018

\begin{abstract}
We report a facile synthetic method for the preparation of titanium-tantalum oxide by means of a modified Adam's method. This new method allowed obtaining $\mathrm{Ti}_{0.8} \mathrm{Ta}_{0.2} \mathrm{O}_{2}$ with a high surface area $\left(234 \mathrm{~m}^{2} \mathrm{~g}^{-1}\right)$, to be used as catalyst support for Pd nanoparticles. Cyclic voltammetry and linear sweep voltammetry measurements confirm the noticeable oxygen reduction reaction (ORR) activities of the $\mathrm{Pd} / \mathrm{Ti}_{0.8} \mathrm{Ta}_{0.2} \mathrm{O}_{2}$ electrocatalyst in alkaline electrolytes, along with a high-selectivity towards a $4 \mathrm{e}^{-}$pathway. The good ORR performance for the $\mathrm{Pd} / \mathrm{Ti}_{0.8} \mathrm{Ta}_{0.2} \mathrm{O}_{2}$ could arise from both the strong metal-support interaction and the contribution of the $\mathrm{Ti}_{0.8} \mathrm{Ta}_{0.2} \mathrm{O}_{2}$ in facilitating the ORR process, acting as co-catalyst. However, the stability of this catalyst seems insufficient for practical applications.
\end{abstract}

Keywords Titanium $\cdot$ Tantalum $\cdot$ Oxides $\cdot$ Oxygen reduction reaction $\cdot$ Alkaline electrolyte

\section{Introduction}

Oxygen reduction is the most challenging electrochemical reaction for many electrochemical devices, such as fuel cells and metal-air batteries [1-5]. The high potential of this reaction (1.23 V vs. reversible hydrogen electrode, RHE) forces the use of highly active and stable catalysts, being Pt-based ones the most employed [6-10]. However, it is widely known the high cost of this metal; thus, several strategies are sought to replace it [11-13]. There has been a huge increment of

Cinthia Alegre

alegre@liftec.unizar-csic.es

$\triangle$ Vincenzo Baglio

baglio@itae.cnr.it

Stefania Siracusano

siracusano@itae.cnr.it

Esterina Modica

modica@itae.cnr.it

Antonino S. Aricò

arico@itae.cnr.it

1 Istituto di Tecnologie Avanzate per l'Energia, Nicola Giordano, CNR-ITAE, Salita Santa Lucia Sopra Contesse, 5, 98126 Messina, Italy

2 Laboratorio de Investigación en Fluidodinámica y Tecnologías de la Combustión, LIFTEC, CSIC-University of Zaragoza, María de Luna 10, 50018 Saragossa, Spain papers dealing with alternatives to $\mathrm{Pt}$, like the use of other noble metals like Pd, Ag, Au and/or their alloys [14-20] or the use of non-noble metal catalysts, usually based on transition metals disperse onto a carbon matrix (phthalocyanines, ferrocenes, Co-based catalysts, doped-graphene, etc.) [12, 21-24]. Additionally, the dispersion of noble metal nanoparticles on high surface area carbon supports is acknowledge as a good strategy to reduce the amount of expensive active phases [25-28]. However, under the conditions of a fuel cell or a metal-air battery, carbon-based catalysts suffer from the corrosion of the support [29,30].

There has been a great interest in developing alternative supports, such as the ones based on titanium dioxide. $\mathrm{TiO}_{2}$ has been recognized as a versatile material, easy to produce and with a wide variety of applications (solar cells, degradation of organic pollutants, electrocatalysts supports, etc.) [31-35]. It features relatively low cost, non-toxicity, photostability, and inertness [31, 34]. However, depending on the application, increasing the electrical conductivity of $\mathrm{TiO}_{2}$ is necessary. Heating $\mathrm{TiO}_{2}$ in a reducing atmosphere or doping with cations of higher valence (transition metals) are strategies usually pursued to enhance the electrical conductivity; however, at the expense of the specific surface area [34-38]. Several authors have introduced different dopants such as $\mathrm{Nb}, \mathrm{W}, \mathrm{V}, \mathrm{Ta}$, etc., by different methods to enhance the electronic conductivity maintaining an adequate surface area [34, 35, 37, 39, 40]. For example, Beauger et al. synthesized 
$\mathrm{TiO}_{2}$ aerogels and xerogels doped with $\mathrm{Nb}, \mathrm{V}$ and $\mathrm{Ta}$ as alternative to conventional carbon black supports for PEMFCs [36]. Wang et al. obtained $\mathrm{TaNbTiO}_{2}$ and C-TaNbTiO as hybrid supports for Pt-Pd nanoparticles for the ORR [34]. Stassi et al. [41] supported a Pt-Co alloy on Ta-doped $\mathrm{TiO}_{2}$ and Siracusano et al. studied bared and doped $\mathrm{TiO}_{2}$ as catalysts supports for fuel cells [42]. In all cases, doped- $\mathrm{TiO}_{2}$ showed an increased resistance to corrosion.

The different properties of $\mathrm{TiO}_{2}$, such as surface area, crystallographic structure, etc., depend on the synthesis method. There have been many synthetic methods studied in literature, like sol-gel processes, hydrothermal and solvothermal routes, reverse microemulsion methods, etc. [33, 40].

Herein, we propose a new synthetic method to prepare $\mathrm{TiO}_{2}$ doped with $\mathrm{Ta}$, having a porous structure, to be used as the support for Pd nanoparticles. The prepared Pd supported on TiTa-oxide electrocatalyst was investigated, in the present work, for the oxygen reduction reaction in alkaline media. Pd nanoparticles have been already demonstrated as a suitable catalyst for the ORR in basic electrolytes [14, 43-45]. The advantages of this method are the easy scalability and simplicity, leading to the preparation of a highly porous $\mathrm{TiO}_{2}$-based support doped with Ta, what increases its electrical conductivity. The stability and activity towards the ORR in alkaline electrolyte of the Pd/TiTa-oxide electrocatalyst was compared to a commercial $\mathrm{Pd} / \mathrm{C}$ based material.

\section{Experimental}

\section{Materials and methods}

Titanium-tantalum oxides were synthesized by the Adams fusion method using the procedure modified by Marshall $[46,47] . \mathrm{TiCl}_{4}\left(98 \%\right.$, Fluka) and $\mathrm{TaCl}_{5}(99.8 \%$, SigmaAldrich) metal precursors were added to isopropanol (99.5\%, Sigma-Aldrich) to obtain a total metal concentration of $0.08 \mathrm{M}$. This solution was magnetically stirred at room temperature for $1 \mathrm{~h}$ to ensure the complete dissolution of the precursors. Then $\mathrm{NaNO}_{3}(99.0 \%$, Sigma-Aldrich), previously grounded in ball-milling, was added to the isopropanol solution under vigorous stirring. The slurry was then heated at $90{ }^{\circ} \mathrm{C}$ under constant stirring, until obtaining a humid paste, which was dried in a ventilated oven at $90{ }^{\circ} \mathrm{C}$ for $24 \mathrm{~h}$. The dry salt was then placed in a furnace at $500{ }^{\circ} \mathrm{C}$ for $30 \mathrm{~min}$. The fused salt oxide was washed with distilled water to remove the remaining salts, filtered and dried in an oven at $80{ }^{\circ} \mathrm{C}$ for $12 \mathrm{~h}$.

The so-obtained TiTa-oxide was employed as the support for Pd nanoparticles synthesized by a sulphite complex methodology. Firstly, a Pd-sulphite complex was prepared by reaction of $\mathrm{PdCl}_{2}$ (99.9\%, Strem Chemicals) with sodium bisulfite (99.995\%, Aldrich). Once obtained, the Pd-sulphite salt was first dissolved in acidic solution and subsequently decomposed with $\mathrm{H}_{2} \mathrm{O}_{2}(40 \% \mathrm{p} / \mathrm{v}$, Titolchimica) to form a colloidal dispersion of $\mathrm{PdO}_{\mathrm{x}}$ that was impregnated on the oxide support. The as-formed catalyst was reduced in $\mathrm{H}_{2}$ atmosphere (10 wt\% in Ar) at $25^{\circ} \mathrm{C}$ to obtain Pd metal nanoparticles supported on the TiTa-oxide with a loading of $60 \mathrm{wt} \%$ of Pd [45].

\section{Physico-chemical characterization}

Several characterization techniques were employed to investigate the different physico-chemical features of both the support, TiTa-oxide, and the catalyst, Pd/TiTa-oxide. $\mathrm{X}$-ray diffraction (XRD) was performed with $\mathrm{Cu} \mathrm{K} \alpha$ radiation operating at $40 \mathrm{kV}$ and $20 \mathrm{~mA}$ in a Philips X-pert $3710 \mathrm{X}$-ray diffractometer. The diffraction patterns were fitted to Joint Committee on Powder Diffraction Standards (JCPDS). The peaks broadening was used to calculate the crystallite size by the Debye-Scherrer equation after correction for the instrumental broadening. The morphology of the samples and their composition were studied by scanning electron microscopy (SEM) and energy dispersive X-ray (EDX) analysis, carried out by a FEI XL30 SFEG microscope. The instrument was operated at $25 \mathrm{kV}$ and the EDX probe was used to determine the bulk elemental composition of the samples. Transmission electron microscopy (TEM) analysis was performed with a FEI CM12 microscope by depositing some drops of the samples dispersed in isopropyl alcohol on carbon film-coated $\mathrm{Cu}$ grids. The specific surface area of the oxide support was calculated by the Brunauer-Emmett-Teller (BET) equation and nitrogen adsorption-desorption isotherms, measured at $-196{ }^{\circ} \mathrm{C}$, using an ASAP $2020 \mathrm{M}$ Micrometrics.

\section{Electro-chemical characterization}

The electrochemical studies were carried out using a standard three-electrode cell and an Autolab potentiostat/galvanostat with GPES software and connected to a rotating disk electrode. A glassy carbon electrode (GC, $5 \mathrm{~mm}$ in diameter) was used as the working electrode, a platinum mesh was used as the counter and an $\mathrm{Hg} \mid \mathrm{HgO}$ electrode was used as the reference electrode. Typically, $5 \mathrm{mg}$ of the catalyst was dispersed in $5 \mathrm{~mL}$ of a mixture of isopropanol (99.5\%, Sigma-Aldrich) and water (Milli Q water, $18.2 \mathrm{M} \Omega \mathrm{cm}$ ) in a $3: 1 \mathrm{v} / \mathrm{v}$ ratio and sonicated for $30 \mathrm{~min} .30 \mathrm{wt} \%$ of Nafion (5\%, Ion Power) was added as polymer binder. Then, $15 \mu \mathrm{L}$ of the catalyst ink was dropped onto the glassy carbon electrode to obtain a metal loading of $50 \mu \mathrm{g} \mathrm{cm}{ }^{-2}$ of Pd and allowed to dry at room temperature for $15 \mathrm{~min}$ to obtain a uniform carbon film. All electrochemical experiments were carried out at room temperature and ambient pressure using 
$1 \mathrm{M} \mathrm{KOH} \mathrm{(90 \% ,} \mathrm{Sigma-Aldrich)} \mathrm{as} \mathrm{the} \mathrm{electrolyte} \mathrm{solution.}$ Linear sweep voltammetries from $0.65 \mathrm{~V}$ vs. RHE to $0.25 \mathrm{~V}$ vs. RHE were performed at a scan rate of $5 \mathrm{mV} \mathrm{s}^{-1}$ at different rotation rate: 100, 200, 400, 1000, 1600 and $2500 \mathrm{rpm}$, bubbling pure $\mathrm{O}_{2}$ in the electrolyte. Before the measurements, the electrode was repeatedly potentiodynamically swept, with a scan rate of $100 \mathrm{mV} \mathrm{s}^{-1}$, from 0 to $1.2 \mathrm{~V} \mathrm{vs}$ RHE in the deaerated (degassed with $\mathrm{He}$ ) $1 \mathrm{M} \mathrm{KOH}$ solution until a steady voltammogram was obtained. The durability of the TiTaOx-based catalyst was assessed by potential cycling between 0.6 and $1.2 \mathrm{~V}$ vs. RHE, bubbling He, until 5000 cycles were completed. The activity of the catalyst was evaluated before and after the cycles by linear sweep voltammetries at different rotation speeds (as previously detailed).

The Pd/TiTa-oxide catalyst was compared to a commercial catalyst employing a carbonaceous support, $30 \% \mathrm{Pd} / \mathrm{C}$ (E-TEK).

\section{Results and discussion}

The oxide support was initially characterized in terms of structure, morphology and surface area. The textural parameters for the TiTa-oxide support, obtained by $\mathrm{N}_{2}$ physisorption, are shown in Table 1. The specific surface area, determined applying the BET equation to the adsorption-desorption isotherms (shown in Fig. 1), is $234 \mathrm{~m}^{2} \mathrm{~g}^{-1}$. TiTa-oxide shows the characteristic features of a type IV isotherm, mesoporous solid [48]. The hysteresis loop at high $P / P_{\mathrm{o}}$ is associated with capillary condensation taking place in mesopores. The mesoporosity of the oxide support favors the diffusion of reagents towards the catalytic centers. The calcination temperature is mild enough to not compromise the textural properties of the support.

Figure 2 shows SEM images of the TiTa-oxide support at different magnification. The support presents a granulated morphology, with a mixture of small and large particles agglomerates. However, a porous structure is observed. The EDX analysis was employed to investigate the elemental bulk composition of the doped-oxide support, being $\mathrm{Ti}: \mathrm{Ta}=80.5: 19.5$, in agreement with the nominal one. From

Table 1 Textural parameters obtained by $\mathrm{N}_{2}$-physisorption on TiTaoxide

\begin{tabular}{|c|c|c|c|c|c|}
\hline $\begin{array}{l}\text { Textural } \\
\text { param- } \\
\text { eters }\end{array}$ & $\begin{array}{l}\text { Specific } \\
\text { surface } \\
\text { area } \\
\left(\mathrm{S}_{\text {B.E. }}\right) / \\
\mathrm{m}^{2} \mathrm{~g}^{-1}\end{array}$ & $\begin{array}{l}\text { Micropore } \\
\text { surface } \\
\text { area/m } \mathrm{m}^{2} \\
\mathrm{~g}^{-1}\end{array}$ & $\begin{array}{l}\text { Pore } \\
\text { volume } \\
\left(\mathrm{V}_{\mathrm{p}}\right) / \mathrm{cm}^{3} \\
\mathrm{~g}^{-1}\end{array}$ & $\begin{array}{l}\text { Micropore } \\
\text { volume } \\
\left(\mathrm{V}_{\mathrm{mp}}\right) / \mathrm{cm}^{3} \\
\mathrm{~g}^{-1}\end{array}$ & $\begin{array}{l}\text { Pore size/ } \\
\mathrm{nm}\end{array}$ \\
\hline $\begin{array}{l}\text { TiTa- } \\
\text { oxide }\end{array}$ & 234 & 12 & 0.32 & 0.003 & 8.7 \\
\hline
\end{tabular}

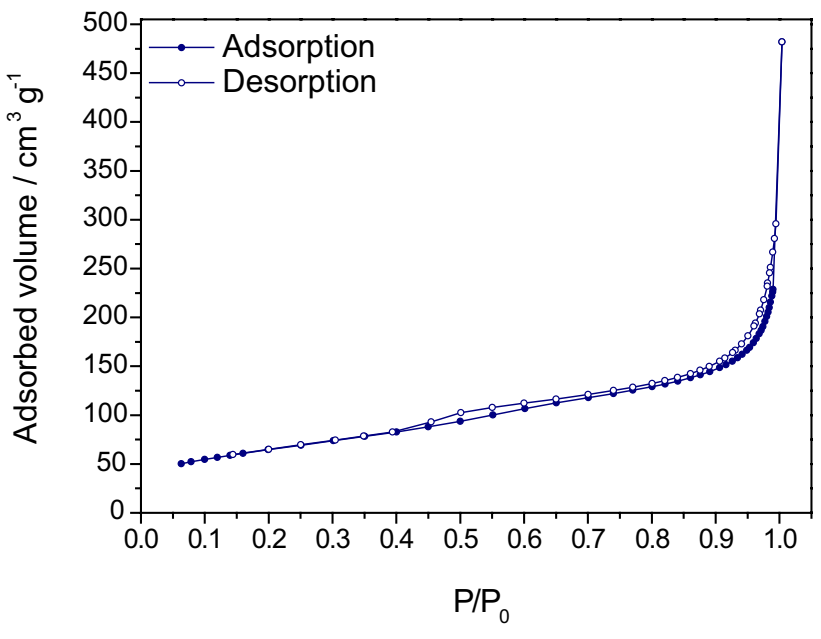

Fig. $1 \mathrm{~N}_{2}$-adsorption/desorption isotherm for the TiTa-oxide support

now on, TiTa-oxide will be expressed as $\mathrm{Ti}_{0.8} \mathrm{Ta}_{0.2} \mathrm{O}_{2}$, considering the ratio obtained by EDX.

Figure 3 presents the X-ray diffraction patterns for the $\mathrm{Ti}_{0.8} \mathrm{Ta}_{0.2} \mathrm{O}_{2}$ support and the corresponding Pd catalyst. As evidenced from the graph, $\mathrm{Ti}_{0.8} \mathrm{Ta}_{0.2} \mathrm{O}_{2}$ is not entirely crystalline (peaks are not clearly defined); however, the main phase observed is anatase. The calcination temperature employed during the synthesis, $500{ }^{\circ} \mathrm{C}$, is not high enough to fully crystallize the amorphous oxide obtained after the synthesis. $\mathrm{Pd} / \mathrm{Ti}_{0.8} \mathrm{Ta}_{0.2} \mathrm{O}_{2}$ catalyst shows the typical peaks of the $\mathrm{Pd}$ crystallographic structure, faced-centered cubic, with main reflections at $40^{\circ}, 47^{\circ}, 68^{\circ}, 82^{\circ}$ and $86^{\circ}$ (JCPDS Card No. 46-1043). Crystallite size was calculated by applying the Scherrer's equation to the peak at $68^{\circ}$ (corresponding to the (220) plane). The catalyst showed a crystallite size of $4.5 \mathrm{~nm}$, which is higher than that of the commercial $30 \%$ $\mathrm{Pd} / \mathrm{C}$ (E-TEK) [49], used for the electrochemical comparison, with crystallite size equal to $3.4 \mathrm{~nm}$. The difference in the crystal size might be ascribed to the different metallic loading, being $60 \mathrm{wt} \%$ for the $\mathrm{Pd} / \mathrm{Ti}_{0.8} \mathrm{Ta}_{0.2} \mathrm{O}_{2}$ catalyst, in comparison to $\mathrm{Pd} / \mathrm{C}$ (E-TEK), with a $30 \mathrm{wt} \%$.

TEM micrographs for the Pd-based catalyst supported on $\mathrm{Ti}_{0.8} \mathrm{Ta}_{0.2} \mathrm{O}_{2}$ are shown in Fig. 4 at low (Fig. 4a) and high (Fig. 4b) magnification. Figure 4a shows the $\mathrm{Ti}_{0.8} \mathrm{Ta}_{0.2} \mathrm{O}_{2}$ (light spots) fully covered with Pd particles (dark spots). The high metallic loading ( $60 \mathrm{wt} \%$ ) employed in the synthesis of the $\mathrm{Pd} / \mathrm{Ti}_{0.8} \mathrm{Ta}_{0.2} \mathrm{O}_{2}$ catalyst is responsible for this agglomeration. Titanium-tantalum based oxides are not so electronically conductive as carbon materials, even though doping with $\mathrm{Ta}$ increases the conductivity of the material [36]. It has already been proved that doping $\mathrm{TiO}_{2}$ with cations of a higher valence, such as Ta, favors the presence of oxygen vacancies that will increase the electronic conductivity, due to the concentration of positively charged defects in the lattice $[4,33]$. In any case, to favour the electronic

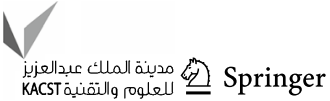



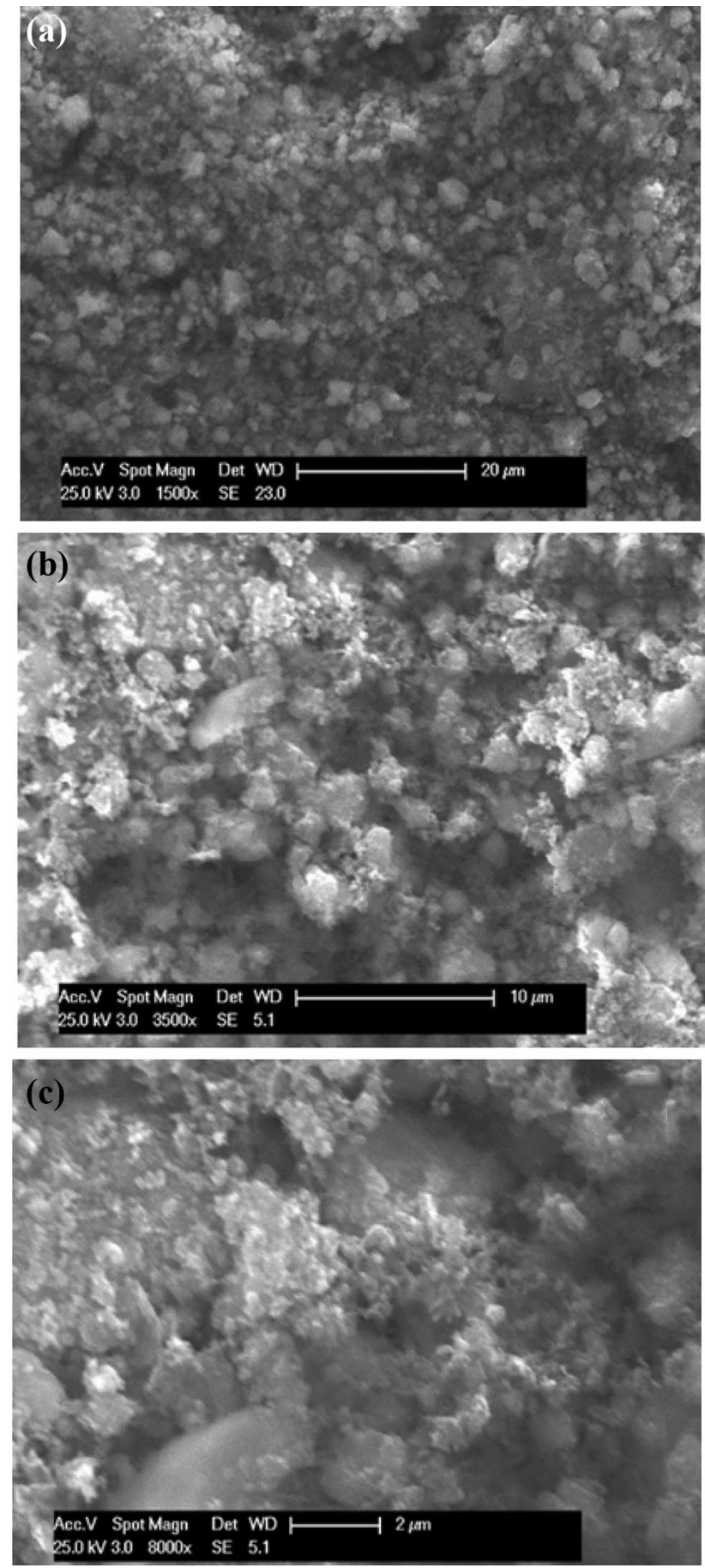

Fig. 2 SEM images for the TiTa-oxide support obtained at different magnification: $(\mathbf{a}) \times 1500,(\mathbf{b}) \times 3500$ and $(\mathbf{c}) \times 8000$

percolation also through the metallic nanoparticles, the $\mathrm{Pd} /$ $\mathrm{Ti}_{0.8} \mathrm{Ta}_{0.2} \mathrm{O}_{2}$ was synthesized with a high metallic loading (60 wt\%), determined by SEM-EDX. Figure $4 \mathrm{~b}$ shows an image at higher magnification in which metallic Pd particles and the $\mathrm{Ti}_{0.8} \mathrm{Ta}_{0.2} \mathrm{O}_{2}$ support are clearly observed. The average Pd particle size, determined from TEM images, is

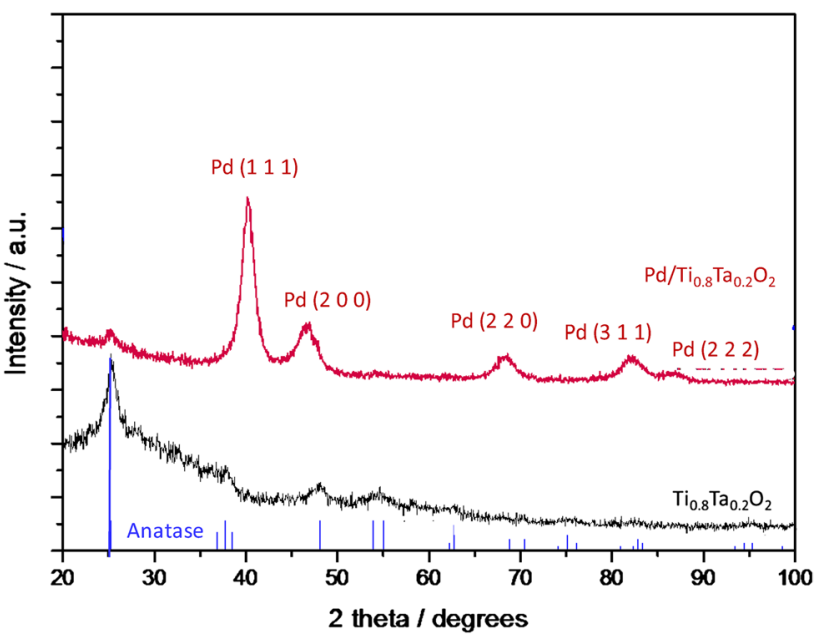

Fig. 3 XRD diffraction patterns for $\mathrm{Ti}_{0.8} \mathrm{Ta}_{0.2} \mathrm{O}_{2}$ and $\mathrm{Pd} / \mathrm{Ti}_{0.8} \mathrm{Ta}_{0.2} \mathrm{O}_{2}$ catalyst

about $5 \mathrm{~nm}$. On the other hand, the $\mathrm{Pd} / \mathrm{C}$ commercial catalyst shows an average particle size of $4.3 \mathrm{~nm}$ [49].

The behavior of the $\mathrm{Pd} / \mathrm{Ti}_{0.8} \mathrm{Ta}_{0.2} \mathrm{O}_{2}$ catalyst in comparison to $\mathrm{Pd} / \mathrm{C}$ (E-TEK) was investigated for the oxygen reduction reaction (ORR) in an alkaline solution with a rotating disk electrode (RDE). Titanium-based materials have been widely studied in literature as supports for noble metal catalysts such as Pt or Au and mainly in acid media [50-52]. Recently, there has been a growing interest of this type of catalysts for alkaline media [53,54], also in combination with carbon materials $[55,56]$. Up to our knowledge, Pd supported on Ta-doped titanium oxide has not been studied in alkaline electrolytes until now. For example, Elezovic et al. studied a $\mathrm{Nb}-\mathrm{TiO}_{2}$ supported Pt catalyst in comparison with Vulcan supported one, showing similar catalytic activity towards oxygen reduction. Maltanava et al. studied the electrocatalytic activity of both bare high-ordered $\mathrm{TiO}_{2}$ nanotubes (TNTs) and gold nanoparticles (Au NPs) loaded TNTs toward ORR. They determined that the overpotential of $\mathrm{O}_{2}$ reduction on the surface of Au NPs with a definite size increases with increasing the annealing temperature of $\mathrm{TiO}_{2}$ support. In general, it has been thoroughly proved that titanium-based supports seem to enhance the catalytic activity of noble metals towards the ORR in alkaline media.

The electrochemically active surface area (ECSA) was first evaluated in a deaerated $1 \mathrm{M} \mathrm{KOH}$ solution by cyclic voltammetry from 0.05 to $1.2 \mathrm{~V}$ vs. RHE, at a scan rate of $100 \mathrm{mV} \mathrm{s}^{-1}$ (not shown) as previously described in [45]. Briefly, ECSA was determined from the integration of the peak related to Pd-oxide reduction (between 0.4 and $0.8 \mathrm{~V}$ vs. RHE), assuming $405 \mu \mathrm{C} \mathrm{cm}^{-2}$ for the reduction of a monolayer of Pd-oxide [45].

The ECSA for the $\mathrm{Pd} / \mathrm{Ti}_{0.8} \mathrm{Ta}_{0.2} \mathrm{O}_{2}$ catalyst was of $25.8 \mathrm{~m}^{2} \mathrm{~g}^{-1}$, whereas for the $\mathrm{Pd} / \mathrm{C}$ was $69.7 \mathrm{~m}^{2} \mathrm{~g}^{-1}$, 
Fig. 4 TEM micrographs for $\mathrm{Pd} / \mathrm{Ti}_{0.8} \mathrm{Ta}_{0.2} \mathrm{O}_{2}$ at (a) low and (b) high magnification
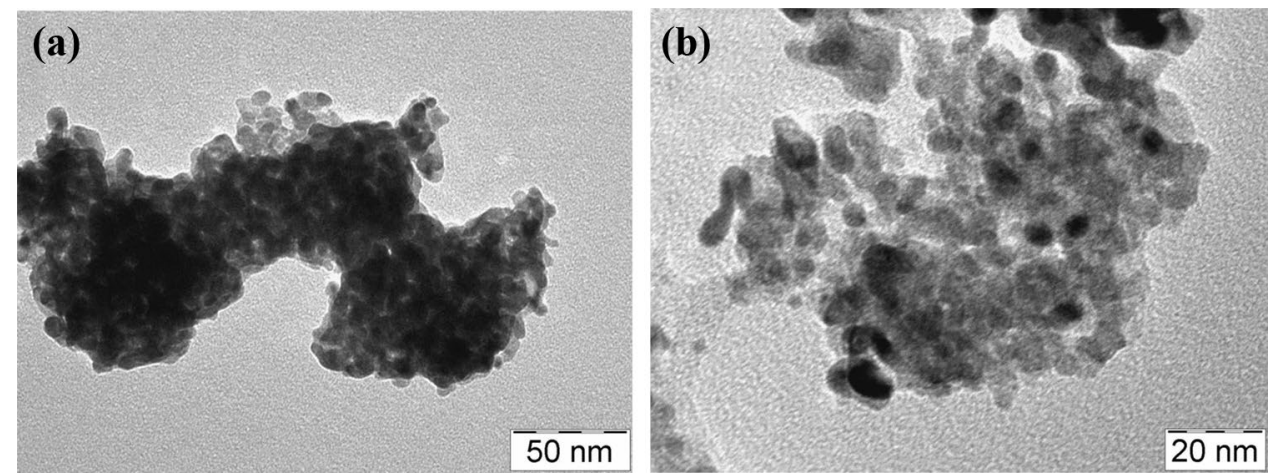

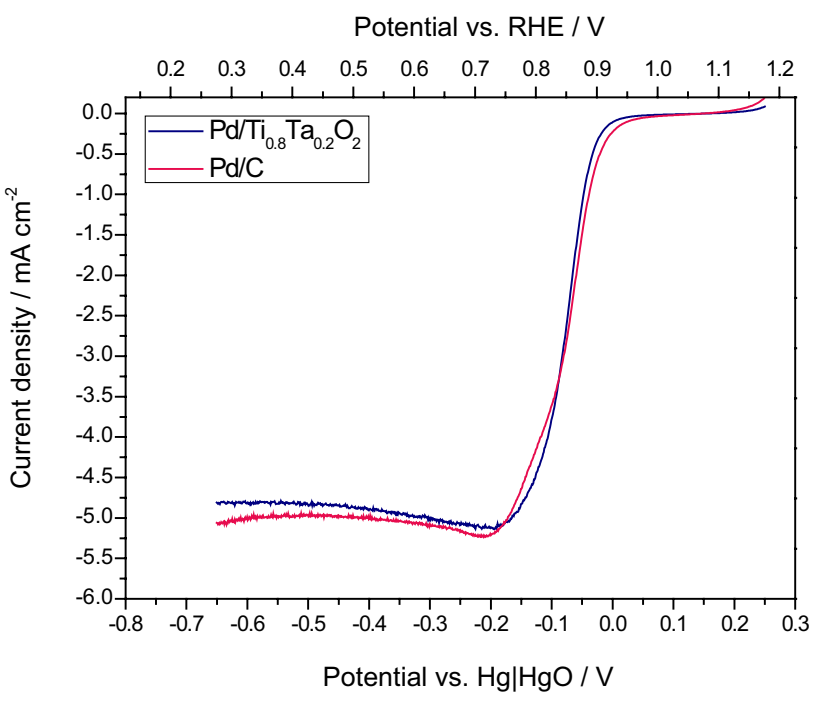

Fig. 5 Polarization curves in an $\mathrm{O}_{2}$-saturated $1 \mathrm{M} \mathrm{KOH}$ solution at $\omega=1600 \mathrm{rpm}$; scan rate $5 \mathrm{mV} \mathrm{s}^{-1}$. Pd loading on the glassy carbon electrode $50 \mu \mathrm{g} \mathrm{cm}^{-2}$ of $\mathrm{Pd}$

significantly higher due to the lower concentration of metal (30 wt \%) on the carbonaceous support and, thus, a better nanoparticle dispersion [49].

Figure 5 shows the polarization curves for both catalysts in an $\mathrm{O}_{2}$-saturated $1 \mathrm{M} \mathrm{KOH}$ solution at $1600 \mathrm{rpm}$. $\mathrm{Pd} / \mathrm{C}(\mathrm{E}-\mathrm{TEK})$ and $\mathrm{Pd} / \mathrm{Ti}_{0.8} \mathrm{Ta}_{0.2} \mathrm{O}_{2}$ present a very similar performance towards the ORR. The carbon-based catalyst shows a slightly better onset potential and limiting current density, what might be due to its higher ECSA. However, the presence of $\mathrm{Ti}_{0.8} \mathrm{Ta}_{0.2} \mathrm{O}_{2}$ may favour the activity of this catalyst towards the ORR in alkaline electrolyte, allowing to obtain a similar performance. It has been proved that the catalytic activity toward the ORR of $\mathrm{TiO}_{2}$-based catalysts depends on both the structural properties and the fabrication procedure. For example, spray-deposited anatase and single crystal rutile type $\mathrm{TiO}_{2}$ exhibit a $4 \mathrm{e}^{-}$pathway in alkaline electrolytes; whereas amorphous titanium oxides exhibit $2 \mathrm{e}^{-}$pathway [32, 33]. Sacco et al. determined that anatase $\mathrm{TiO}_{2}$ nanotubes were as active for the ORR in alkaline media as commercial Pt-catalysts [33]. Mentus et al. demonstrated the activity of anodically grown $\mathrm{TiO}_{2}$ towards the ORR in alkaline media, reaching values of current density around 6-7 $\mathrm{mA} \mathrm{cm}^{-2}$. Pei et al. showed that $\mathrm{TiO}_{2}$ single crystals [particularly, (001) high-energy facets] are highly active towards the ORR in alkaline media [57]. Anatase-type $\mathrm{TiO}_{2}$ is also active towards ORR, but not as much as the former. Pei et al. ascribed the enhanced activity to the oxygen vacancies in non stoichiometric $\mathrm{TiO}_{2}$ [57]. In our case, doping $\mathrm{TiO}_{2}$ with Ta creates oxygen vacancies that could contribute to the enhancement of the activity towards the ORR. The crystallographic structure of our $\mathrm{Ti}_{0.8} \mathrm{Ta}_{0.2} \mathrm{O}_{2}$, in the prevalent form of anatase, also contributes to the enhancement of the activity. With an engineered design of the crystallographic orientation of TaTi-oxide crystals, this activity could be further enhanced, as demonstrated by Pei et al. [57] or Liu et al. [58]. On the other hand, a review conducted by Trasatti et al. [59] showed that the activity towards the ORR of noble metals supported on titanium-based supports is increased due to the strong metal support interaction (SMSI) effect, a fact that has been proved by other authors in more recent papers [34, 41, 60]. In summary, both the intrinsic activity of titanium-based materials towards the ORR in alkaline media and the SMSI effect might be responsible for the significant activity of our $\mathrm{Pd} / \mathrm{Ti}_{0.8} \mathrm{Ta}_{0.2} \mathrm{O}_{2}$ catalyst.

Figure 6 presents Koutecky-Levich (K-L) plots obtained for both catalysts. The K-L plots show a linear behavior of the inverse of the current density with the reciprocal of the square root of the rotation speed. By applying the Levich equation [61] to the linear fitting of the experimental data, from the slope (B) we calculate the transferred electron number $(n)$. The diffusion coefficient of oxygen in the electrolyte (D), the cinematic viscosity of the electrolyte $(\nu)$, and the bulk concentration of oxygen in the electrolyte $\left(\mathrm{C}^{*}\right)$ are taken from Ref. [62]. Both catalysts follow a $4 \mathrm{e}^{-}$pathway, being $3.8 \mathrm{e}^{-}$for $\mathrm{Pd} / \mathrm{Ti}_{0.8} \mathrm{Ta}_{0.2} \mathrm{O}_{2}$ and $3.9 \mathrm{e}^{-}$for commercial $\mathrm{Pd} / \mathrm{C}$.

The assessment of the stability was carried out by potential cycling between 0.6 and $1.2 \mathrm{~V}$ vs. RHE, shown in Fig. 7 . Both samples present a significant decay in performance, 

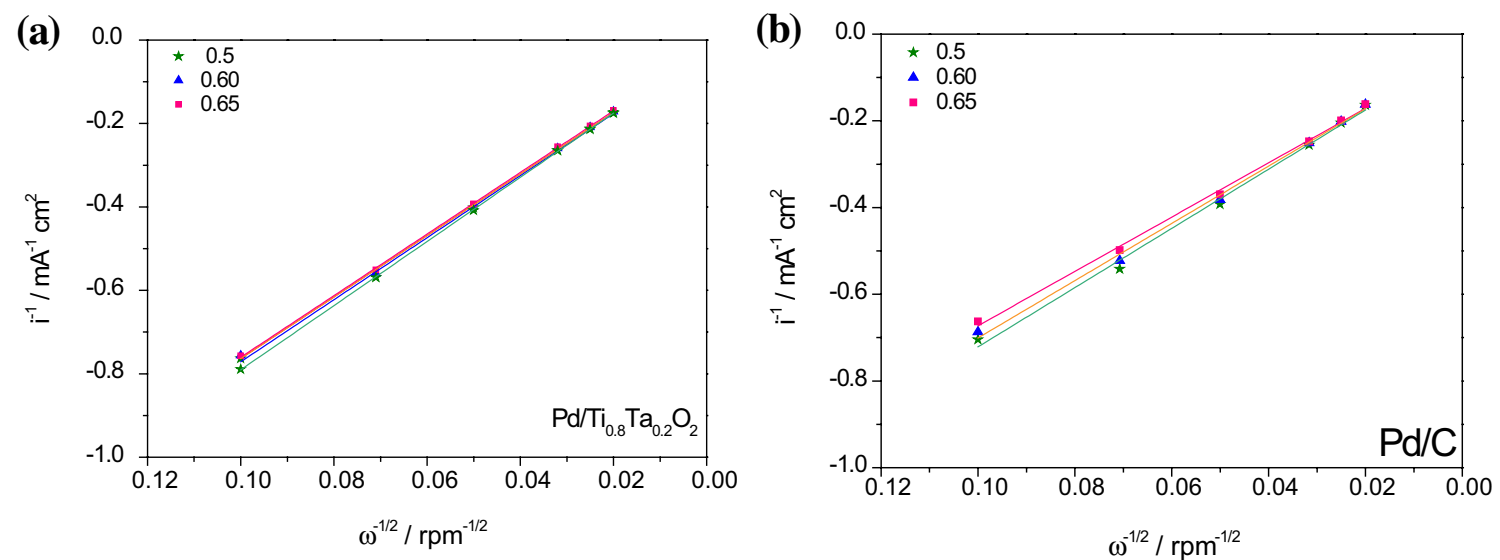

Fig. 6 (a) Levich plots for the $\mathrm{Pd} / \mathrm{Ti}_{0.8} \mathrm{Ta}_{0.2} \mathrm{O}_{2}$ and (b) $\mathrm{Pd} / \mathrm{C}$ (E-TEK) catalysts. Potentials are referred to the RHE and currents are per unit of geometric area. Electrolyte solution is a $1.0 \mathrm{M} \mathrm{KOH}$ solution at $25^{\circ} \mathrm{C}$
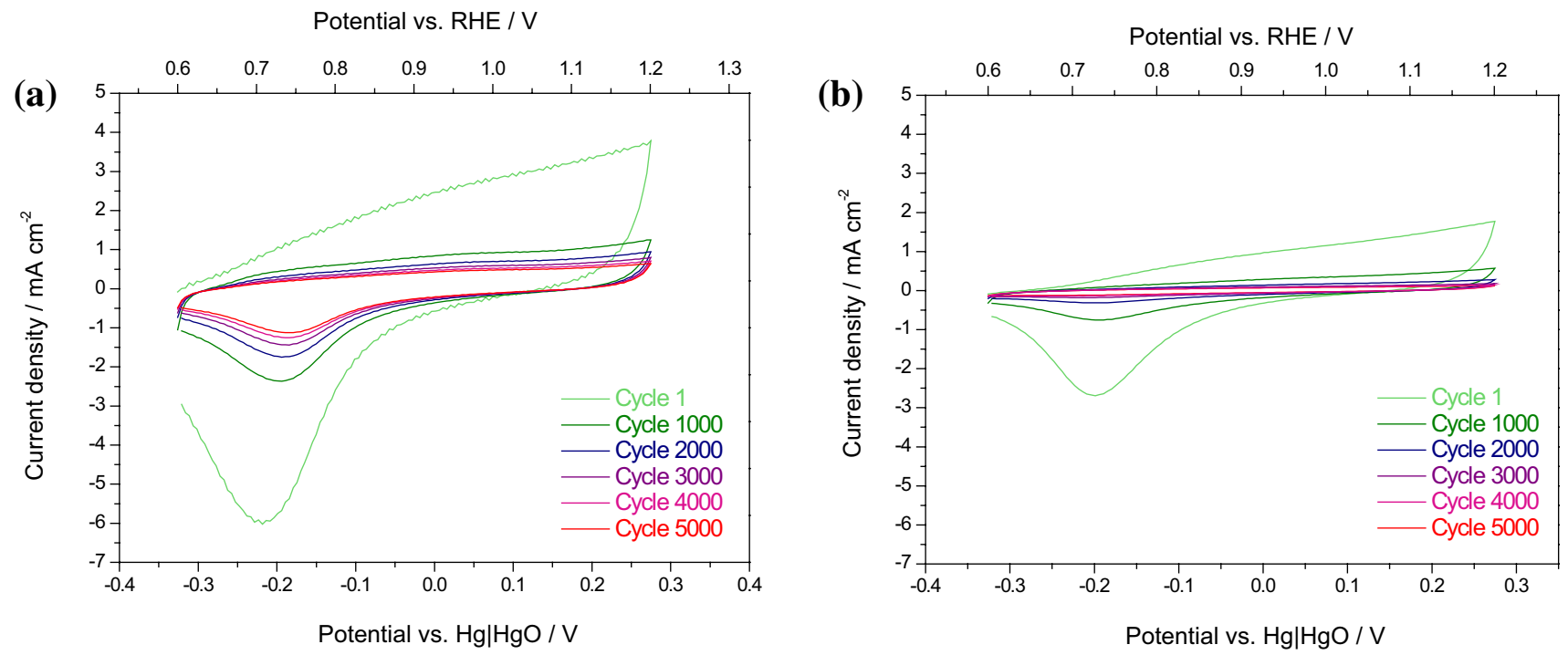

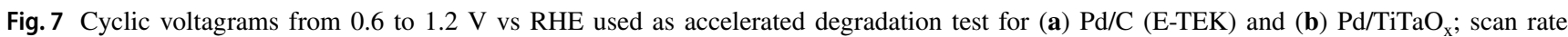
$100 \mathrm{mV} \mathrm{s}^{-1}$. $1.0 \mathrm{M} \mathrm{KOH}$ solution at $25^{\circ} \mathrm{C}$ as electrolyte

determined by the reduction of the area of the peak at ca. $0.7 \mathrm{~V}$ vs. RHE.

The activity (Fig. 8) and the ECSA (Fig. 9) were evaluated before and after the 5000 cycles. The decay in performance for the $\mathrm{Pd} / \mathrm{Ti}_{0.8} \mathrm{Ta}_{0.2} \mathrm{O}_{2}$ catalyst is remarkable, losing around $54 \mathrm{mV}$ in terms of onset potential and a $25 \%$ in terms of limiting current density, as can be ascertained from Fig. 8 . However, Pd/C E-TEK, even though possessing a carbon support, widely known for its tendency to corrosion, suffers a lower decay in performance of around $16 \mathrm{mV}$ in terms of onset potential and around $16 \%$ in terms of limiting current density. This is also corroborated by the ECSA losses, shown in Fig. 9. Pei et al. ascribed the poorer stability of $\mathrm{TiO}_{2}$ polycrystals to their anatase-rutile mixed crystal phase [57]. In our case, both the anatase crystallographic structure and the fact of being a semi-crystalline material could be responsible for the poor stability of the titanium-based support.

Cyclic voltamograms in Fig. 9 show the H-adsorption/ desorption peaks around $0.2 \mathrm{~V}$ vs. RHE both in the anodic and the cathodic sense. The Pd oxidation peak is visible in the range 1.0-1.2 V vs. RHE (anodic sense) and the reduction of the Pd-oxide formed is visible at around $0.7 \mathrm{~V}$ vs. RHE (cathodic sense). The size of this peak is significantly higher for the commercial catalyst in comparison to the TiTaOx-based one, indicating a higher ECSA for the Pd/C (E-TEK), as previously described. Besides, in the case of the commercial catalyst (Fig. 9a), there is a shoulder at $0.6 \mathrm{~V}$ vs RHE that could be ascribed to the oxidation of the 


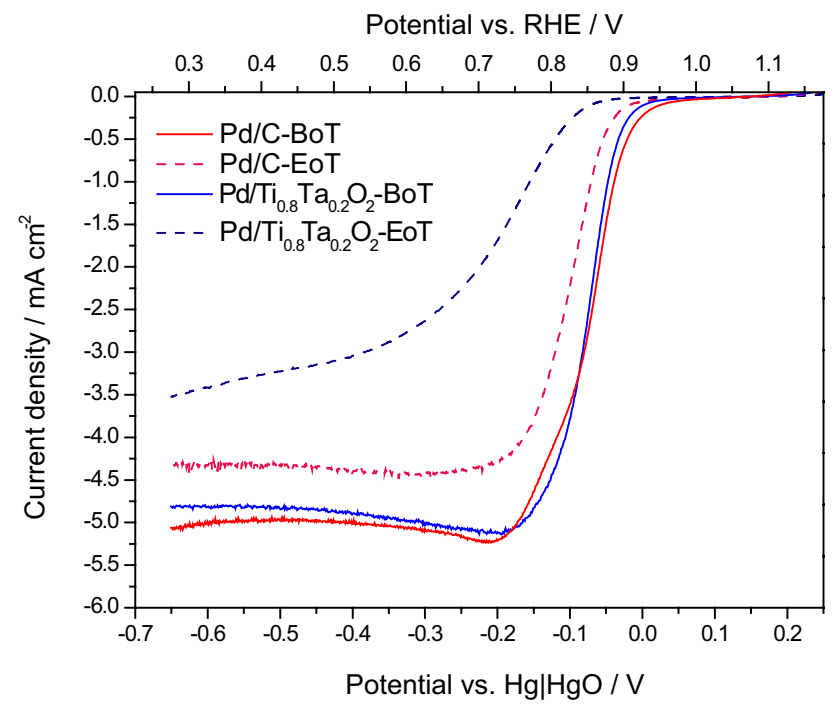

Fig. 8 Polarization curves at the beginning of the test (BoT) and at the end of the test (EoT) in an $\mathrm{O}_{2}$-saturated $1 \mathrm{M} \mathrm{KOH}$ solution at $\omega=1600 \mathrm{rpm}$; scan rate $5 \mathrm{mV} \mathrm{s}^{-1}$. Pd loading on the glassy carbon electrode: $50 \mu \mathrm{g} \mathrm{cm}^{-2}$ of $\mathrm{Pd}$. $1.0 \mathrm{M} \mathrm{KOH}$ solution at $25{ }^{\circ} \mathrm{C}$ as electrolyte

carbon support. After 5000 cycles, the width of the voltammogram (red line) is severely reduced for both catalysts. ECSA calculated from the charge associated to the reduction of the Pd-oxide peak (0.7 V vs RHE) was $7.6 \mathrm{~m}^{2} \mathrm{~g}^{-1}$ for the $\mathrm{Pd} / \mathrm{C}$ (E-TEK) catalyst (Fig. 9a) and $0.44 \mathrm{~m}^{2} \mathrm{~g}^{-1}$ for $\mathrm{Pd} /$ $\mathrm{Ti}_{0.8} \mathrm{Ta}_{0.2} \mathrm{O}_{2}$ (Fig. 9b). This explains the considerable decay in performance towards the ORR measured by linear sweep voltammetry in previously shown Fig. 8. From these results, it is clear that, although $\mathrm{Ti}_{0.8} \mathrm{Ta}_{0.2} \mathrm{O}_{2}$ synthesized by this new method presents a good activity for the ORR, this support is not stable enough for a practical application.

\section{Conclusions}

A new method for the synthesis of Ta-doped titanium oxides was proposed. The Adam's method permits obtaining considerable amounts of oxide in a reproducible way with a good compromise between surface area and crystallinity.

$\mathrm{Pd}$ nanoparticles were supported on the as-prepared $\mathrm{Ti}_{0.8} \mathrm{Ta}_{0.2} \mathrm{O}_{2}$ and studied as a catalyst for the oxygen reduction reaction in alkaline media. The activity of $\mathrm{Pd} /$ $\mathrm{Ti}_{0.8} \mathrm{Ta}_{0.2} \mathrm{O}_{2}$ was very similar to that of a commercial $\mathrm{Pd} / \mathrm{C}$ catalyst. The activity of the titanium-based catalyst was ascribed to both the strong metal support interaction effect and to the intrinsic activity of the $\mathrm{Ti}_{0.8} \mathrm{Ta}_{0.2} \mathrm{O}_{2}$ towards the ORR in alkaline solution. Stability tests were carried out by potential cycling. Results determined that the $\mathrm{Ti}_{0.8} \mathrm{Ta}_{0.2} \mathrm{O}_{2}$ synthesized by this new method is not stable, leading to a loss of performance of the catalyst of a $25 \%$ in terms of current density. The lack of stability of the support was attributed to the crystallographical structure, being semi-crystalline anatase less stable than other crystallographic phases of titanium-based materials. Future studies will center on the study of the calcination temperature, to increase both conductivity and crystallinity notwithstanding the excellent textural properties of the oxide support.

Acknowledgements The research leading to these results has received funding from the "Accordo di Programma CNR-MiSE, Gruppo
Potential vs. RHE / V

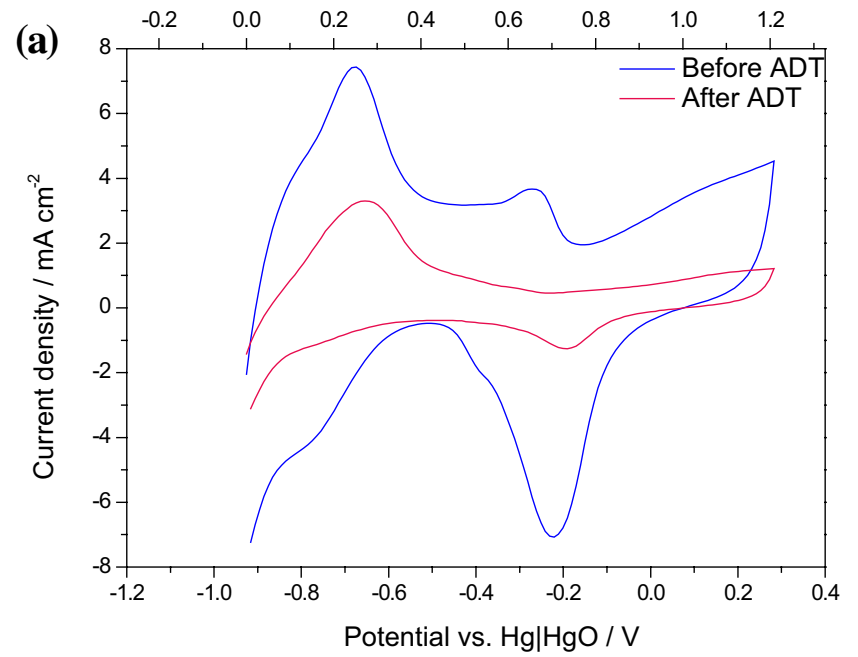

Potential vs. RHE / V

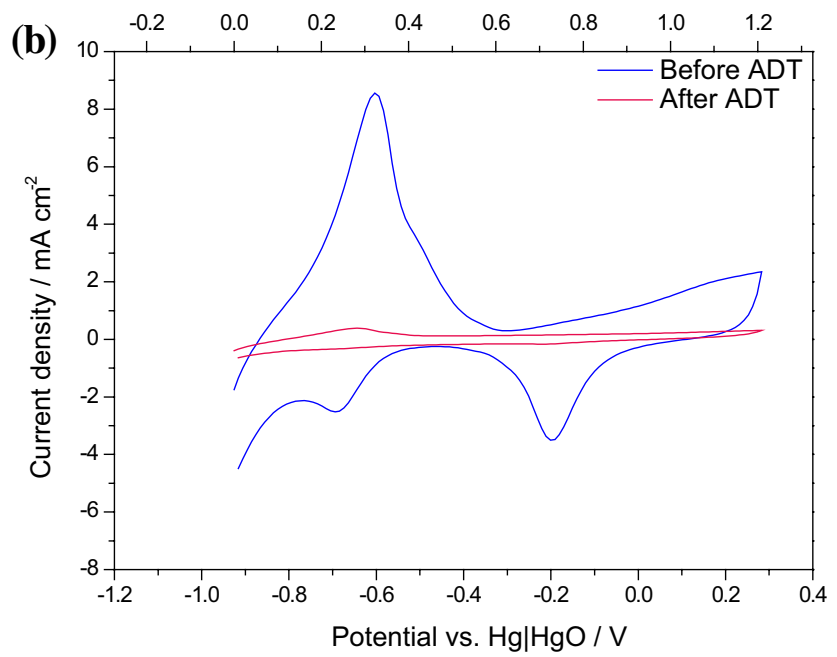

Fig. 9 Cyclic voltagrams from 0 to $1.2 \mathrm{~V}$ vs RHE before (blue line) and after (red line) the accelerated degradation test for (a) $\mathrm{Pd} / \mathrm{C}$ and (b) $\mathrm{Pd} /$ $\mathrm{Ti}_{0.8} \mathrm{Ta}_{0.2} \mathrm{O}_{2}$; scan rate $100 \mathrm{mV} \mathrm{s}^{-1}$. $1.0 \mathrm{M} \mathrm{KOH}$ solution at $25^{\circ} \mathrm{C}$ as electrolyte 
tematico Sistema Elettrico Nazionale e Progetto: Sistemi elettrochimici per l'accumulo di energia',

Open Access This article is distributed under the terms of the Creative Commons Attribution 4.0 International License (http://creativeco mmons.org/licenses/by/4.0/), which permits unrestricted use, distribution, and reproduction in any medium, provided you give appropriate credit to the original author(s) and the source, provide a link to the Creative Commons license, and indicate if changes were made.

\section{References}

1. Neburchilov, V., Wang, H., Martin, J.J., Qu, W.: A review on air cathodes for zinc-air fuel cells. J. Power Sources 195, 1271-1291 (2010). https://doi.org/10.1016/j.jpowsour.2009.08.100

2. Dresp, S., Luo, F., Schmack, R., Kühl, S., Gliech, M., Strasser, P.: An efficient bifunctional two-component catalyst for oxygen reduction and oxygen evolution in reversible fuel cells, electrolyzers and rechargeable air electrodes. Energy Environ. Sci. 9, 2020-2024 (2016). https://doi.org/10.1039/C6EE01046F

3. Narayan, S.R., Manohar, A.K., Mukerjee, S.: Bi-Functional Oxygen Electrodes-Challenges and Prospects. Electrochem. Soc. Interface. Summer 24, 65-69 (2015)

4. Jörissen, L.: Bifunctional oxygen/air electrodes. J. Power Sources 155, 23-32 (2006). https://doi.org/10.1016/j.jpows our.2005.07.038

5. Caramia, V., Bozzini, B.: Materials science aspects of zinc-air batteries: a review. Mater. Renew. Sustain. Energy 3, 28 (2014). https://doi.org/10.1007/s40243-014-0028-3

6. Gasteiger, H.A., Kocha, S.S., Sompalli, B., Wagner, F.T.: Activity benchmarks and requirements for Pt, Pt-alloy, and non-Pt oxygen reduction catalysts for PEMFCs. Appl. Catal. B Environ. 56, 9-35 (2005). https://doi.org/10.1016/j.apcatb.2004.06.021

7. Van Der Vliet, D., Wang, C., Debe, M., Atanasoski, R., Markovic, N.M., Stamenkovic, V.R.: Platinum-alloy nanostructured thin film catalysts for the oxygen reduction reaction. Electrochim. Acta 56, 8695-8699 (2011). https://doi.org/10.1016/j.elect acta.2011.07.063

8. Wang, Y., Leung, D.Y.C., Xuan, J., Wang, H.: A review on unitized regenerative fuel cell technologies, part-A: unitized regenerative proton exchange membrane fuel cells. Renew. Sustain. Energy Rev. 65, 961-977 (2016). https://doi.org/10.1016/j. rser.2016.07.046

9. Mani, P., Srivastava, R., Strasser, P.: Dealloyed binary PtM3 $(\mathrm{M}=\mathrm{Cu} \mathrm{Co}, \mathrm{Ni})$ and ternary $\mathrm{PtNi} 3 \mathrm{M}(\mathrm{M}=\mathrm{Cu} \mathrm{Co}, \mathrm{Fe}, \mathrm{Cr})$ electrocatalysts for the oxygen reduction reaction: performance in polymer electrolyte membrane fuel cells. J. Power Sources 196, 666-673 (2011). https://doi.org/10.1016/j.jpowsour.2010.07.047

10. Sebastián, D., Serov, A., Artyushkova, K., Gordon, J., Atanassov, P., Aricò, A.S., Baglio, V.: High performance and cost-effective direct methanol fuel cells: Fe-N-C methanol-tolerant oxygen reduction reaction catalysts. Chemsuschem 9, 1986-1995 (2016). https://doi.org/10.1002/cssc.201600583

11. Bashyam, R., Zelenay, P.: A class of non-precious metal composite catalysts for fuel cells. Nature 443, 63-66 (2006). https://doi. org/10.1038/nature05118

12. Chen, Z., Higgins, D., Yu, A., Zhang, L., Zhang, J., Heller, A., Hui, S.Q., Zhang, J.J., Ota, K., Campbell, S.A., Dahn, J.R., Olson, T., Pylypenko, S., Atanassov, P., Ustinov, E.A.: A review on nonprecious metal electrocatalysts for PEM fuel cells. Energy Environ. Sci. 4, 3167 (2011). https://doi.org/10.1039/c0ee00558d
13. Karim, N.A., Kamarudin, S.K.: An overview on non-platinum cathode catalysts for direct methanol fuel cell. Appl. Energy 103, 212-220 (2013). https://doi.org/10.1016/j.apenergy.2012.09.031

14. McKerracher, R., Alegre, C., Baglio, V., Aricò, A.S., Ponce de León, C., Mornaghini, F., Rodlert, M., Walsh, F.C.: A nanostructured bifunctional $\mathrm{Pd} / \mathrm{C}$ gas-diffusion electrode for metal-air batteries. Electrochim. Acta 174, 508-515 (2015). https://doi. org/10.1016/j.electacta.2015.06.001

15. Miller, H.A., Lavacchi, A., Vizza, F., Marelli, M., Di Benedetto, F., D’Acapito, F., Paska, Y., Page, M., Dekel, D.R.: A $\mathrm{Pd} / \mathrm{C}-\mathrm{CeO}_{2}$ Anode catalyst for high-performance platinum-free anion exchange membrane fuel cells. Angew. Chemie Int. Ed. 55, 6004-6007 (2016). https://doi.org/10.1002/anie.201600647

16. Félix-Navarro, R.M., Beltrán-Gastélum, M., Reynoso-Soto, E.A., Paraguay-Delgado, F., Alonso-Nuñez, G., Flores-Hernández, J.R.: Bimetallic Pt-Au nanoparticles supported on multiwall carbon nanotubes as electrocatalysts for oxygen reduction. Renew. Energy. 87, 31-41 (2016). https://doi.org/10.1016/j. renene.2015.09.060

17. Macak, J.M., Schmidt-Stein, F., Schmuki, P.: Efficient oxygen reduction on layers of ordered $\mathrm{TiO} 2$ nanotubes loaded with $\mathrm{Au}$ nanoparticles. Electrochem. Commun. 9, 1783-1787 (2007). https://doi.org/10.1016/j.elecom.2007.04.002

18. Shao, M.: Palladium-based electrocatalysts for hydrogen oxidation and oxygen reduction reactions. J. Power Sources 196, 2433-2444 (2011). https://doi.org/10.1016/j.jpows our.2010.10.093

19. Lo Vecchio, C., Alegre, C., Sebastián, D., Stassi, A., Aricò, A.S., Baglio, V.: Investigation of supported Pd-based electrocatalysts for the oxygen reduction reaction: performance. Mater. (Basel). 8, 7997-8008 (2015). https://doi.org/10.3390/ma8125438

20. Abo Zeid, E.F., Ibrahem, I.A.: Preparation, characterization and electrocatalytic activity for oxygen reduction reaction in PEMFCs of bimetallic PdNi nanoalloy. Mater. Renew. Sustain. Energy 6, 19 (2017). https://doi.org/10.1007/s40243-017-0103-7

21. Hong, W.T., Risch, M., Stoerzinger, K.A., Grimaud, A., Suntivich, J., Shao-Horn, Y.: Toward the rational design of non-precious transition metal oxides for oxygen electrocatalysis. Energy Environ. Sci. 8, 1404-1427 (2015). https://doi.org/10.1039/C4EE0 3869J

22. Jaouen, F., Proietti, E., Lefèvre, M., Chenitz, R., Dodelet, J.-P., Wu, G., Chung, H.T., Johnston, C.M., Zelenay, P.: Recent advances in non-precious metal catalysis for oxygen-reduction reaction in polymer electrolyte fuelcells. Energy Environ. Sci. 4, 114-130 (2011). https://doi.org/10.1039/C0EE00011F

23. Cao, R., Lee, J.-S.S., Liu, M., Cho, J.: Recent progress in nonprecious catalysts for metal-air batteries. Adv. Energy Mater. 2, 816-829 (2012). https://doi.org/10.1002/aenm.201200013

24. Alegre, C., Busacca, C., Di Blasi, O., Antonucci, V., Aricò, A.S., Di Blasi, A., Baglio, V.: A combination of $\mathrm{CoO}$ and Co nanoparticles supported on electrospun carbon nanofibers as highly stable air electrodes. J. Power Sources 364, 101-109 (2017). https://doi. org/10.1016/j.jpowsour.2017.08.007

25. Antolini, E.: Carbon supports for low-temperature fuel cell catalysts. Appl. Catal. B Environ. 88, 1-24 (2009). https://doi. org/10.1016/j.apcatb.2008.09.030

26. García, G., Roca-Ayats, M., Lillo, A., Galante, J.L., Peña, M.A., Martínez-Huerta, M.V.: Catalyst support effects at the oxygen electrode of unitized regenerative fuel cells. Catal. Today 210, 67-74 (2013). https://doi.org/10.1016/j.cattod.2013.02.003

27. S. L. Suib, F. Maillard, N. Job, M. Chatenet, Chapter 14Approaches to Synthesize Carbon-Supported Platinum-Based Electrocatalysts for Proton-Exchange Membrane Fuel Cells, New Futur. Dev. Catal., 2013: pp. 407-428. https://doi.org/10.1016/ b978-0-444-53880-2.00019-3 
28. S.L. Suib, F. Maillard, N. Job, M. Chatenet, Chapter 17 - Basics of PEMFC Including the Use of Carbon-Supported Nanoparticles, in: New Futur. Dev. Catal., 2013: pp. 401-423. https://doi. org/10.1016/b978-0-444-53874-1.00018-4

29. Maass, S., Finsterwalder, F., Frank, G., Hartmann, R., Merten, C.: Carbon support oxidation in PEM fuel cell cathodes. J. Power Sources 176, 444-451 (2008). https://doi.org/10.1016/j.jpows our.2007.08.053

30. Castanheira, L., Dubau, L., Mermoux, M., Berthomé, G., Caqué, N., Rossinot, E., Chatenet, M., Maillard, F.: Carbon corrosion in proton-exchange membrane fuel cells: from model experiments to real-life operation in membrane electrode assemblies. ACS Catal. 4, 2258-2267 (2014). https://doi.org/10.1021/cs500449q

31. Cabello, G., Davoglio, R.A., Pereira, E.C.: Microwave-assisted synthesis of anatase-TiO2 nanoparticles with catalytic activity in oxygen reduction. J. Electroanal. Chem. 794, 36-42 (2017). https ://doi.org/10.1016/j.jelechem.2017.04.004

32. Mentus, S.V.: Oxygen reduction on anodically formed titanium dioxide. Electrochim. Acta 50, 27-32 (2004). https://doi. org/10.1016/j.electacta.2004.07.009

33. Sacco, A., Garino, N., Lamberti, A., Pirri, C.F., Quaglio, M.: Anodically-grown $\mathrm{TiO}_{2}$ nanotubes: effect of the crystallization on the catalytic activity toward the oxygen reduction reaction. Appl. Surf. Sci. 412, 447-454 (2017). https://doi.org/10.1016/j. apsusc.2017.03.224

34. Wang, Y.-J., Wilkinson, D.P., Neburchilov, V., Song, C., Guest, A., Zhang, J.: Ta and $\mathrm{Nb}$ co-doped $\mathrm{TiO}_{2}$ and its carbon-hybrid materials for supporting Pt-Pd alloy electrocatalysts for PEM fuel cell oxygen reduction reaction. J. Mater. Chem. A. 2, 12681 (2014). https://doi.org/10.1039/C4TA02062F

35. Lv, H., Zhang, G., Hao, C., Mi, C., Zhou, W., Yang, D., Li, B., Zhang, C.: activity of $\mathrm{IrO}_{2}$ supported on tantalum-doped $\mathrm{TiO}_{2}$ electrocatalyst for solid polymer electrolyte water electrolyzer. RSC Adv. 7, 40427-40436 (2017). https://doi.org/10.1039/ C7RA06534E

36. Beauger, C., Testut, L., Berthon-Fabry, S., Georgi, F., Guetaz, $\mathrm{L}$.: Doped $\mathrm{TiO}_{2}$ aerogels as alternative catalyst supports for proton exchange membrane fuel cells: a comparative study of $\mathrm{Nb}, \mathrm{v}$ and Ta dopants. Microporous Mesoporous Mater. 232, 109-118 (2016). https://doi.org/10.1016/j.micromeso.2016.06.003

37. Stodolny, M., Laniecki, M.: Synthesis and characterization of mesoporous $\mathrm{Ta}_{2} \mathrm{O}_{5}-\mathrm{TiO}_{2}$ photocatalysts for water splitting. Catal. Today 142, 314-319 (2009). https://doi.org/10.1016/j.catto d.2008.07.034

38. Siracusano, S., Baglio, V., D’Urso, C., Antonucci, V., Aricò, A.S.: Preparation and characterization of titanium suboxides as conductive supports of $\mathrm{IrO}_{2}$ electrocatalysts for application in SPE electrolysers. Electrochim. Acta 54, 6292-6299 (2009). https:// doi.org/10.1016/j.electacta.2009.05.094

39. C. Hao, H. Lv, B. Li, H. Xin, J. Ma, Investigation of mesoporous vanadium doped $\mathrm{TiO} 2$ support for anode catalyst of SPE electrolyzer, Taiyangneng Xuebao/Acta Energiae Solaris Sin. 34 (2013) 1464-1470. http://www.scopus.com/inward/record.url?eid=2s2.0-84886859703\&partnerID $=$ tZOtx3y 1

40. Cavaliere, S., Subianto, S., Savych, I., Jones, D.J., Rozière, J.: Electrospinning: designed architectures for energy conversion and storage devices. Energy Environ. Sci. 4, 4761 (2011). https://doi. org/10.1039/c1ee02201f

41. Stassi, A., Gatto, I., Baglio, V., Passalacqua, E., Aricò, A.S.: Oxide-supported PtCo alloy catalyst for intermediate temperature polymer electrolyte fuel cells. Appl. Catal. B Environ. 142-143, 15-24 (2013). https://doi.org/10.1016/j.apcatb.2013.05.008

42. Siracusano, S., Stassi, A., Modica, E., Baglio, V., Aricò, A.S.S.: Preparation and characterisation of Ti oxide based catalyst supports for low temperature fuel cells. Int. J. Hydrogen
Energy 38, 11600-11608 (2013). https://doi.org/10.1016/j.ijhyd ene.2013.04.161

43. McKerracher, R.D., Figueredo-Rodríguez, H.A., Ponce de León, C., Alegre, C., Baglio, V., Aricò, A.S., Walsh, F.C.: A highperformance, bifunctional oxygen electrode catalysed with palladium and nickel-iron hexacyanoferrate. Electrochim. Acta 206, 127-133 (2016). https://doi.org/10.1016/j.electacta.2016.04.090

44. Alegre, C., Modica, E., Lo Vecchio, C., Sebastián, D., Lázaro, M.J., Aricò, A.S., Baglio, V.: Carbon nanofibers as advanced Pd catalyst supports for the air electrode of alkaline metal-air batteries. Chempluschem. 80, 1384-1388 (2015). https://doi. org/10.1002/cplu.201500120

45. Alegre, C., Modica, E., Lo Vecchio, C., Siracusano, S., Aricò, A.S., Baglio, V.: Pd supported on Ti-suboxides as bifunctional catalyst for air electrodes of metal-air batteries. Int. J. Hydrogen Energy 41, 19579-19586 (2016). https://doi.org/10.1016/j.ijhyd ene.2016.03.095

46. Marshall, A., Børresen, B., Hagen, G., Tsypkin, M., Tunold, R.: Preparation and characterisation of nanocrystalline $\operatorname{IrxSn} 1-\mathrm{xO}_{2}$ electrocatalytic powders. Mater. Chem. Phys. 94, 226-232 (2005). https://doi.org/10.1016/j.matchemphys.2005.04.039

47. Siracusano, S., Van Dijk, N., Payne-Johnson, E., Baglio, V., Aricò, A.S.: Nanosized IrOx and IrRuOx electrocatalysts for the $\mathrm{O}_{2}$ evolution reaction in PEM water electrolysers. Appl. Catal. B Environ. 164, 488-495 (2015). https://doi.org/10.1016/j.apcat b.2014.09.005

48. Sing, K.S.W.: Reporting physisorption data for gas, solid systems with special reference to the determination of surface area and porosity (Recommendations, 1984). Pure Appl. Chem. 57, 603-619 (1985). https://doi.org/10.1351/pac198557040603

49. Rivera Gavidia, L., Sebastián, D., Pastor, E., Aricò, A., Baglio, V.: Carbon-supported Pd and PdFe alloy catalysts for direct methanol fuel cell cathodes. Materials (Basel). 10, 580 (2017). https://doi. org/10.3390/ma10060580

50. Bauer, A., Chevallier, L., Hui, R., Cavaliere, S., Zhang, J., Jones, D., Rozière, J.: Synthesis and characterization of $\mathrm{Nb}^{-\mathrm{TiO}}{ }_{2}$ mesoporous microsphere and nanofiber supported Pt catalysts for high temperature PEM fuel cells. Electrochim. Acta 77, 1-7 (2012). https://doi.org/10.1016/J.ELECTACTA.2012.04.028

51. Huang, D., Zhang, B., Bai, J., Zhang, Y., Wittstock, G., Wang, M., Shen, Y.: Pt catalyst supported within $\mathrm{TiO}_{2}$ mesoporous films for oxygen reduction reaction. Electrochim. Acta 130, 97-103 (2014). https://doi.org/10.1016/J.ELECTACTA.2014.02.115

52. Kim, J.-H., Ishihara, A., Mitsushima, S., Kamiya, N., Ota, K.-I.: Catalytic activity of titanium oxide for oxygen reduction reaction as a non-platinum catalyst for PEFC. Electrochim. Acta 52, 2492 2497 (2007). https://doi.org/10.1016/j.electacta.2006.08.059

53. Chanmanee, W., de Tacconi, N.R., Rajeshwar, K., Lin, W.-Y., Nikiel, L., Wampler, W.A.: Photocatalytically generated trimetallic (Pt-Pd-Au/C-TiO ${ }_{2}$ nanocomposite electrocatalyst. J. Electrochem. Soc. 159, F226-F233 (2012). https://doi. org/10.1149/2.038207jes

54. Tammeveski, K., Tenno, T., Rosental, A., Talonen, P., Johansson, L.-S., Niinistö, L.: The reduction of oxygen on Pt-TiO[sub 2] coated Ti electrodes in alkaline solution. J. Electrochem. Soc. 146, 669 (1999). https://doi.org/10.1149/1.1391660

55. Tiido, K., Alexeyeva, N., Couillard, M., Bock, C., MacDougall, B.R., Tammeveski, K.: Graphene-TiO 2 composite supported Pt electrocatalyst for oxygen reduction reaction. Electrochim. Acta 107, 509-517 (2013). https://doi.org/10.1016/J.ELECT ACTA.2013.05.155

56. Jukk, K., Kozlova, J., Ritslaid, P., Sammelselg, V., Alexeyeva, N., Tammeveski, K.: Sputter-deposited Pt nanoparticle/multiwalled carbon nanotube composite catalyst for oxygen reduction reaction. J. Electroanal. Chem. 708, 31-38 (2013). https://doi. org/10.1016/J.JELECHEM.2013.09.009

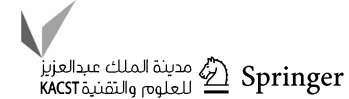


57. Pei, D.-N., Gong, L., Zhang, A.-Y., Zhang, X., Chen, J.-J., Mu, Y., Yu, H.-Q.: Defective titanium dioxide single crystals exposed by high-energy 001 facets for efficient oxygen reduction. Nat. Commun. 6, 8696 (2015). https://doi.org/10.1038/ncomms9696

58. Liu, S., Yu, J., Jaroniec, M.: Anatase $\mathrm{TiO}_{2}$ with dominant highenergy 001 facets: synthesis, properties, and applications. Chem. Mater. 23, 4085-4093 (2011). https://doi.org/10.1021/cm200 $597 \mathrm{~m}$

59. A. Więckowski, Interfacial electrochemistry : theory, experiment, and applications, Marcel Dekker, 1999

60. Park, K.-W., Seol, K.-S.: Nb-TiO 2 supported Pt cathode catalyst for polymer electrolyte membrane fuel cells. Electrochem. Commun. 9, 2256-2260 (2007). https://doi.org/10.1016/j.eleco m.2007.06.027

61. Castegnaro, M.V., Paschoalino, W.J., Fernandes, M.R., Balke, B., Alves, M.C.M., Ticianelli, E.A., Morais, J.: $\mathrm{Pd}-\mathrm{M} / \mathrm{C}(\mathrm{M}=\mathrm{Pd}$,
$\mathrm{Cu}, \mathrm{Pt})$ Electrocatalysts for Oxygen reduction reaction in alkaline medium: correlating the electronic structure with activity. Langmuir 33, 2734-2743 (2017). https://doi.org/10.1021/acs.langm uir.7b00098

62. Dumitru, A., Mamlouk, M., Scott, K.: Effect of different chemical modification of carbon nanotubes for the oxygen reduction reaction in alkaline media. Electrochim. Acta 135, 428-438 (2014). https://doi.org/10.1016/j.electacta.2014.04.123

Publisher's Note Publisher's Note Springer Nature remains neutral with regard to jurisdictional claims in published maps and institutional affiliations. 